How can foresters contribute to the problem of reclaiming surface mined Iand?

What are the mining companies doing?
Implications for foresters are given in two papers here, based on ones presented at the 15th IUFRO Congress, Gainesville, Florida, March 1971.

\title{
Mined-land reclamation in British Columbia
}

\begin{abstract}
The importance of institutional and environmental factors in the formulation of policy
\end{abstract}

\section{J. L. E. HOGG}

Faculty of Forestry

University of British Columbia

Vancouver 8, B.C.

\begin{abstract}
Restauration des terrains minés en Colombie Britannique. Les facteurs institutionnels et du milieu sont discutés dans l'optique de la léigslation qui régit la restauration des terres perturbées par les mines à ciel ouvert en Colombie britannique. Ces deux groupes de facteurs sont très importants lorsqu'il s'agit de fixer équitablement l'intensité de la restauration et la forme que doit prendre la législation. On fait des comparaisons avec l'Europe et les EtatsUnis pour montrer que ces facteurs varient énormément d'un endroit à l'autre et pour expliquer les différences dans les pouvoirs législatifs adoptés pour le contrôle de la restauration.
\end{abstract}

Until a few years ago an attitude prevailed that British Columbia was an inexhaustible source of raw materials, and both government and industry were concerned solely with reaping the harvest. Over the past decade or so the government has guided the Province out of this purely exploitive phase of its resource policy and into a more rational allocation and development of its natural wealth; but, even with this improvement, the prevailing climate of concern for environmental control has brought all spheres of primary resource use under close scrutiny. It is the purpose of this paper to discuss one aspect of environmental control, namely the recently introduced legislation for the regulation of surface mining (1), and how it may affect mining operations in the Province.

Foresters have recently become very involved in the environmental movement and have much to offer the land reclaimer, but they may have been confused about their responsibilities by much of the exaggerated comment from both industry and environmental concerns. It is hoped that this paper will allow foresters to assess their relationship to the problem and to decide how they may contribute to the reclamation of mined land.

\section{The mining industry in British Columbia}

During the past decade the mining industry has experienced an outstanding rate of growth, with production increasing 2.7 times as compared with an increase of 1.99 times in the Gross Provincial Product. The value of mineral production in 1969 was approximately $\$ 464$ million. This figure should increase quite substantially during the next few years due to the rapid development of the extensive coal deposits in south-eastern British Columbia. For example, an economic survey (2) showed that one of the mining companies, Kaiser Resources Ltd., will be extracting coal to the value of around $\$ 80$ million per annum. Thus, the production of primary minerals alone accounts for $5.4 \%$ of the Gross Provincial Product. One must also consider the economic activity which this generates and the value added in the processing of the raw materials. In 1969 the mining industry paid $\$ 57$ million in taxes and, including both primary and processed minerals, exported goods to the value of $\$ 480$ million or about $26 \%$ of total exports.

\section{The adverse effects of mining operations}

The mineral industry is obviously making a significant contribution to our material welfare, but mineral resources are of no value to mankind unless they are brought to the surface to be transformed into goods which we can use ourselves or with which we can generate the capital to purchase or finance the goods and services which we desire, and it is unfortunate that the realization of our mineral wealth has certain side effects which may detract from our total if not our material welfare. 
These effects are well summarized in Kentucky's strip-mining law (3):

The General Assembly finds that the unregulated stripmining of coal causes soil erosion, damage from rolling stones and overburden, landslides, stream pollution, the accumulation of stagnant water and the seepage of contaminated water, increases in the likelihood of floods, destroys the value of land for agricultural purposes, destroys aesthetic values, counteracts efforts for the conservation of soil, water and other natural resources, destroys or impairs the property rights of citizens, creates fire hazards, and in general creates hazards dangerous to life and property so as to cnstitute an imminent and inordinate peril to the welfare of the Commonwealth.

Because of its importance to the Provincial economy, it may not be realistic to place a ban on the mining industry, but these diseconomies should be given careful consideration in the development of any mineral deposit, and the government should provide such regulation of the mining industry as to minimize its injurious effects as much as may be desirable.

Here one comes up against the difficulty of assessing the value of non-market costs and benefits. A monetary value can be put on some of the damaging effects: for example, the extra costs involved in the treatment of polluted water for industrial and domestic use can be assessed relatively easily, although the apportionment of that cost among the various mining operations responsible may present some problems. But how does one put a monetary value on aesthetics? Can any realistic monetary value be assigned to sites of outstanding natural beauty or to wilderness areas in which are protected the last remnants of pre-European conditions? If such sites are mined, their unique features are lost forever. Should not mining be prohibited at such sites so that the choice remains open to us until that time when no alternative mineral sources exist and when we can make a more realistic assessment of the relative values of aesthetic satisfaction and material welfare? Whatever the answer to this question, discussion will be limited to those situations where mining operations are permitted.

Industry does not consider costs which are external to its operations; mining companies which are seeking a return on a large and risky capital investment are not going to reduce their profits voluntarily. If, in an economy where capital is the limiting factor, an individual is faced with the choice between an increase in his material welfare, better hospitals, schools, housing, etc., and the beautification of some mine site, he would not be too concerned about the mine site, especially if it was in a remote area. However, there is a strong lobby of public opinion in favour of reclamation, and, in gauging this, the government must make the difficult decision as to how much social capital should be channelled into surface reclamation. It is the government's responsibility to assess social priorities in the allocation of a limited amount of capital.

\section{Reclamation}

The effects of surface mining can be classified into four categories: damage to the land surface, damage to waterbodies, hazards to public health and property, and aesthetic damage. Reclamation shall be defined as the amelioration of any of these deleterious effects.

Mining operations render the land surface unusable for biologically-based management systems such as forestry, agriculture and grazing. The unstable nature of spoil banks and highwalls also render it unsuitable for building purposes.

In Europe, with its high population density and the great demand for land for almost all uses, it has usually been economically worthwhile to reclaim mine sites for cultivation, recreation or construction. In the eastern United States, where strip-mining for coal has also been carried out for many years, it is generally not as profitable to reclaim land for cultivation because there is a surplus of agricultural land over the current requirements of national policy, although it should be pointed out that some areas have been reclaimed quite profitably. However, even with a lower population density than in Europe, it is still profitable to reclaim areas for recreation and, in certain instances, for construction.

In British Columbia, however, the situation is entirely different. Although agricultural land is not as plentiful as it could be, most of the areas being mined are quite unsuitable for agriculture because of high elevation, rough topography and the naturally poor edaphic conditions of the site. The Province has more than 130 million acres of productive forest land, and so there is little or no incentive to reforest a few thousand acres of abandoned mine sites. The population density over the Province as a whole is so low that, apart from some sand and gravel quarries around Greater Vancouver and Victoria, there is relatively little pressure for mined land to be reclaimed for building purposes. Some mine sites are near enough to population centres and tourist regions to make recreational development worthwhile, but many are very isolated and cannot be reached except by means of the transport lines constructed by the mining companies themselves.

Mining activity can affect both the chemical and physical properties of waterbodies. Some of the rock strata exposed by mining may contain toxic chemicals, some of which react with air and water to form acids. Although of major concern in the eastern United States, where such rock types must not remain exposed after mining, toxicity from this source is not a serious problem in British Columbia. Denuded hillsides and the dumping of unconsolidated material in spoil banks and tailings ponds cause increased erosion and may cause an increase in stream sediment loads. This has serious implications in catchment areas where dams, built either as part of the rapidly developing hydro-electric power system or to supply water for a variety of industrial and domestic uses, may be silted up prematurely. The deleterious effects of increased siltation on fish populations and their spawning grounds must also be taken into account, especially considering the importance of the fishing and tourist industries to the Provincial economy. 
Most of these deleterious effects can be removed, or at least ameliorated, by the grading of pit slopes and spoil banks and the construction of tailings ponds and erosion control dams. Revegetation is usually considered necessary, but this is not always possible in British Columbia. Although natural revegetation can be prolific in the coastal forest regions, some of the sites being mined in the interior of the Province are above the tree line, and revegetation in any form may prove impossible; in such situations one will have to rely solely upon the engineering elements of reclamation.

Hazards to public health and property include landslides, which although infrequent can be disastrous, dust blowing off spoil banks and tailings ponds, causing damage to agricultural crops and discomfort and ill-health to human beings, and stagnant pools of water, which could encourage the breeding of disease-carrying organisms. In Europe, the intimate mosaic of residential, industrial, agricultural and mining land presents serious problems, but in British Columbia the isolated locations of most mine sites allow little damage to property or to agricultural crops, and health hazards will usually be removed for the convenience of the miners and their families.

One of the main reasons for the enactment of the reclamation legislation was the aesthetic damage which would be caused throughout the Province. It is technically possible for most mine sites to be screened by planting rows of trees, and this is usually justifiable in close proximity to permanent communities. Studies by Frank (5) and Barr (6) have illustrated the importance of this type of work in the USA and Britain if industry is to be attracted back to the economically depressed areas, which are usually synonymous with derelict land.

However, one must ask oneself if aesthetic reclamation can be justified in less accessible areas. Many people derive considerable satisfaction from the knowledge that they have magnificent scenery in their country, even if they themselves have little opportunity to see it. Such feelings were well expressed by a Winnipeg man who wrote during the public outcry against strip-mining which led to the introduction of the legislation: "As a Canadian, I feel the Rockies are as much a part of my heritage as that of the residents of British Columbia." However, assuming the need for mining, there is little one can do for those who do not want any mining activity or who do not want any part of their country altered: there is no possibility of complete restoration. Closely allied to this viewpoint is the desire to leave the land in as good a condition as we found it, and not to present future generations with scarred and denuded landscapes: areas isolated at present may become easily accessible in a few decades. Although some of the drier sites may require some seeding and planting, most mine sites in British Columbia appear to be eventually capable of natural revegetation. Is it possible, therefore, to justify the expenditure of large sums of money, to establish a plant cover a few years earlier for aesthetic reasons alone? Indeed, if natural revegetation will occur within a reasonable period of time, it may be argued that future generations can be better served by the investment of that money in projects more beneficial to their total welfare.

Another argument for aesthetic revegetation is British Columbia's expanding tourist industry which now ranks second only to forestry. Many advocates of reclamation claim that tourists will no longer come to the Province if there are mines everywhere. Apart from the fact that mines are not everywhere and are unlikely to be in the future, not everyone finds mine sites unattractive. In fact, several mine sites in the Province are very successful tourist attractions. Personally, I am often fascinated when I come across some evidence of Man's activities in remote areas. This is, perhaps, a sense of history, which must be distinguished from the mere reverence of all things "old".

In concluding this section, it should be noted that early revegetation, whether natural or artificial, will probably be necessary in the majority of situations to reduce damage to waterbodies, and so the additional problem of aesthetics may not be as great as the above paragraphs may suggest.

\section{The reclamation legislation in British Columbia}

Research into reclamation procedures has been carried out for many years in other parts of the world, and techniques are fairly well established, thus allowing for the rather detailed regulations found in the Appalachian States, but in British Columbia relatively little or no work has been done. It is possible to apply what has been learned elsewhere, but no-one quite knows what will happen, for example, at some of the higher elevation sites now being mined. It is for this reason that no detailed regulations have been laid down and that much discretionary power has been given to the Minister of Mines.

Before commencing any surface mining operation, the mining company is required to submit a report stating its intentions with regard to reclamation. This is considered by a seven-man advisory committee consisting of three members from the Department of Lands, Forests and Water Resources, one member from the Department of Agriculture, one from the Department of Recreation and Conservation and two from the Department of Mines and Petroleum Resources. When this committee is satisfied with the report, it is passed on through a cabinet committee to a full cabinet meeting. If the cabinet members are satisfied with the report, they will then authorize, by Order in Council, the granting of a temporary three-year permit and will set the amount of the security bond to be deposited with the Minister of Finance. Along with the report, the company must submit proposals for research to be carried out during the first year of the permit. At the end of the first year, a progress report must be submitted along with proposals for the next year's research program. This procedure will continue until investigations have provided sufficient information to allow the formulation of a sa- 
tisfactory reclamation plan. When this plan is submitted, a permanent permit will be granted. At present the legislation applies only to surface mines although provision is made to extend it, by Order in Council, to any mining operation in the Province.

The legislation is attacked because the responsibility for its administration has been given to the Department of Mines and Petroleum Resources which has assigned specific responsibility for reclamation to only one man, with the rank of Inspector of Mines. The conservation groups want a reclamation division in one of the other natural resource agencies such as exists in Kentucky. Certainly, a larger staff might be desirable to co-ordinate the research which must be carried out and to reduce any duplication of effort, but, unlike the situation in Appalachia, mining has been on a relatively small scale, and there is no great backlog of derelict land that requires such an investment. Personally, I am quite satisfied with the arrangement in British Columbia because many of our reclamation problems are of an engineering nature and can best be overseen by mining engineers, with advice on revegetation coming from other government departments. While in the United States one of the major objections to control of reclamation by a mining inspectorate has been fear of political influence exercised by industry, the personnel of the Mines Department in British Columbia, reflecting British Commonwealth traditions of government, are professional civil servants who are not directly exposed to personal political pressures. I consider that the inter-departmental committee and the availability of the reports to members of the public provide adequate safeguards against the mis-use of discretionary power.

\section{References}

1. MINES REGULATION ACT: STATUTES OF BRITISH COLUMBIA. 1967. Chap. 25. / 1969. Chap. 18, sect. 11. / COAL MINES REGULATION ACT: STATUTES OF BRITISH COLUMBIA. 1969. Chap. 3, sect. 8.

2. HEDLIN MENZIES AND ASSOCIATES LTD., VANCOU. VER, B.C. 1969. The impact of the coal mining operations of Kaiser Resources Ltd. on the Canadian economy. Report prepared for Kaiser Resources Ltd. 97 p.
Despite the apparent inferiority of the legislation to some of the Appalachian statutes, it provides a very practical framework for the very different institutional and environmental conditions found in British Columbia. The actual implementation of the legislation is the subject of a detailed discussion in a paper by Thirgood (6). The first temporary permit was only issued in January, 1970, and so we must wait to see how effective the control will be. The really critical time will come when these temporary permits expire in another year. Certainly, if the public desires reclamation, it would be advisable to continually express this desire so that the initial impetus is not lost, but British Columbians are, at least, lucky that they have the chance to prevent rather than repair environmental damage.

I have pointed out some of the social, economic and political factors which must be considered when assessing the requirements for reclamation in any area and, in doing so, I hope that I have shown how much these factors may vary from place to place. We should not reclaim merely for the sake of reclaiming: as foresters, we must recognize the wider responsibilities of our profession.

\section{Acknowledgements}

The author wishes to thank members of the Faculties of Forestry and Law at the University of British Columbia and of the Provincial Department of Mines and Petroleum Resources for helpful discussion. This paper was written as part of a study for a Master's degree on the interactions of the mining industry with other natural resource interests in British Columbia. The financial assistance of the Faculty of Forestry of the University of British Columbia is gratefully acknowledged.

3. KENTUCKY REVISED STATUTES. 1966. Chap. 350.

4. FRANK, R. M. 1964. A guide for screen and cover planting of trees on anthracite mine-spoil areas. USDA, Forest Serv. Res. Pap. NE-22.

5. BARR, J. 1969. Derelict Britain. Penguin Books. 240 p.

6. THIRGOOD, J. V. 1970. The planned reclamation of mined lands. West. Miner 43 (6): 22-25.

\section{Progress in reclamation research in British Columbia during 1970}

\section{J. V. THIRGOOD and J. R. MATTHEWS}

University of British Columbia

Faculty of Forestry

Vancouver 8, B.C.

Les progrès dans la recherche sur la restauration en Colombie Britannique en 1970. En 1969, le gouvernement de Colombie britannique a introduit dans la législation des articles spéciaux pour la restauration des terrains miniers à ciel ouvert. Les progrès accomplis à la lumière de cette législation sont passés en revue et des suggestions sont faites pour la conduite plus rationnelle du programme de recherche et de développement nécessaire.

There are implications for foresters in the provisions for the reclamation of surface mined lands, introduced by the provincial government of British
Columbia in 1969. This legislation (1) requires the filing of a Reclamation Plan by the mining company, but prior to final acceptance investigations must be made over a period of three years or longer to determine the methods to be employed to reclaim the disturbed land (2). In the methodologies now being developed the establishment of a tree cover will have a major role.

The purpose here is to review progress during the first year of the legislation. This paper is based on 